http://dx.doi.org/10.12775/szhf.2013.016

FRYDERYK SCHILLER

\title{
Przyczynek do kwestii pierwszego ludzkiego społeczeństwa według nici przewodniej Mojżeszowego dokumentu ${ }^{1}$
}

Przejście człowieka do wolności i humanizmu ${ }^{*}$

Opatrzność musiała człowieka przysposobić do życia na pasku instynktu, na którym wciąż jeszcze prowadzone są bezrozumne zwierzęta, a ponieważ ludzki rozum był jeszcze nierozwinięty, czuwała nad nim niczym uważna mamka. Potrzebę [zdobywania] pożywienia odsłoniła przed nim za pomocą głodu i pragnienia, to zaś, czego potrzebował do ich zaspokojenia, w obfitości znajdował wokół siebie, kierując się w ich wyborze powonieniem i smakiem. Dzięki łagodnemu klimatowi ochroniła jego nagość, a dzięki powszechnemu pokojowi zabezpieczyła jego bezbronne życie. O zachowanie jego gatunku zatroszczył się popęd płciowy. Był przeto człowiek doskonały niczym rośliny i zwierzęta. Także jego rozum był już od dawna rozwinięty. Ponieważ przyroda wciąż o nim myślała, troszczyła się o niego i zajmowała się nim, więc jego siły mogły się tym łatwiej i tym swobodniej kierować ku spokojnej kontemplacji, jego rozum, nie zakłócony żadną troską, mógł nie niepokojony

${ }^{1}$ Tytuł oryg. Etwas über die erste Menschengesellschaft nach dem Leitfaden der mosaischen Urkunde, "Thalia" 1790, Bd. 3, Heft 11, s. 3-21 (przyp. tłum.).

* Należy przypomnieć czytelnikowi, że pomysły te powstały pod wpływem rozprawki Kanta [opublikowanej] w „Berliner Monatsschrift”. 
pracować nad mową jako swym narzędziem, a także sposobić się w subtelnej grze myśli. Okiem [istoty] szczęśliwej rozglądał się wokół, po stworzeniu; jego pogodny umysł ujmował bezinteresownie i czysto wszelkie zjawiska, zachowując je dokładnie i szczerze w bystrej pamięci. Łagodny i pogodny był przeto początek człowieka, i musiał być taki, jeśli człowiek miał zyskać siły do czekającej go walki.

Pędziłby żywot wiecznego dziecięcia w pełnym rozkoszy spokoju, a krąg, $\mathrm{w}$ jakim by się poruszał, pozostałby najmniejszy z możliwych: od pożądania do zaspokojenia, od zaspokojenia do odpoczynku, i znowu od odpoczynku do pożądania.

Lecz człowiek był powołany do czegoś innego, a siły, jakie w nim złożono, wzywały go do zupełnie innego szczęścia. To, co natura przejęła za niego w okresie jego niemowlęctwa, teraz powinien wziąć na siebie sam, skoro stał się pełnoletni. Powinien sam stać się twórcą swego szczęścia, i tylko udział, jaki miał [w jego osiągnięciu], powinien określać to szczęście. Stanu niewinności, jaki teraz utracił, powinien na powrót nauczyć się szukać dzięki swe mu rozumowi, i powinien powrócić jako wolny, rozumny duch do raju, z którego, jako roślina i jako stworzenie instynktowne wyszedł. [Wychodząc] $\mathrm{z}$ raju niewiedzy i niewoli, nawet jeśli nastąpi to po wielu stuleciach, powinien zapracować na raj poznania i wolności, a mianowicie na taki raj, gdzie prawom moralnym w swym sercu stanie się równie nieodmiennie posłuszny, jak na początku posłuszny był instynktowi, i jak wciąż jeszcze posłuszne są mu rośliny i zwierzęta. Co przeto było nieuniknione? Co musiało się wydarzyć, by zbliżył się do tego odległego celu? Gdy tylko jego rozum po raz pierwszy spróbował swych sił, natura odrzuciła go precz ze swych opiekuńczych ramion, albo mówiąc bardziej poprawnie, on sam, podniecony popędami, których jeszcze nie znał, i nieświadomy tego, jak wielkiej rzeczy dokonał w tej chwili, sam zerwał się z prowadzącego go paska, i z wciąż jeszcze słabym rozumem, oddalił się od instynktów, rzucił się w dziką grę życia, i podjął się niebezpiecznej drogi ku moralnej wolności. Gdy tylko ów głos Boga w raju, który zakazuje [człowiekowi owocu z] drzewa poznania, zamienimy na głos instynktu, który odpycha go od tego drzewa, wówczas jego domniemane nieposłuszeństwo wobec Bożego zakazu nie będzie niczym innym, jak oderwaniem się od swego instynktu, a zatem będzie pierwszym przejawem jego samodzielności [Selbstthätigkeit], pierwszym śmiałym przedsięwzięciem jego rozumu, pierwszym zaczątkiem jego moralnego istnienia. To oderwanie się człowieka od instynktu, które sprowadziło wprawdzie moralne zło na stworzenie, ale tylko by umożliwić w nim moralne dobro, jest bez żadnego sprze- 
ciwu najszczęśliwszym i największym wydarzeniem w ludzkiej historii; od tej chwili pisze się jego wolność, tu położony został pierwszy daleki kamień węgielny pod jego moralność. Kaznodzieja [Volkslehrer] ma całkowitą rację, gdy to wydarzenie traktuje jako upadek pierwszego człowieka oraz, gdzie to tylko możliwe, wyprowadza z tego pożyteczną moralną naukę; ale filozof ma nie mniej racji, gdy ludzkiej naturze w całości [im Großen] życzy szczęścia w tym ważnym kroku do doskonałości. Pierwszy ma rację, nazywając [to zdarzenie] upadkiem, bo człowiek z niewinnego stworzenia stał się winny, $\mathrm{z}$ doskonałego wychowanka natury - niedoskonałą moralnie istotą, ze szczęśliwego narzędzia - nieszczęśliwym artystą.

Filozof ma rację, nazywając to ogromnym krokiem ludzkości, albowiem człowiek z niewolnika naturalnych popędów stał się w ten sposób swobodnie działającym stworzeniem, $\mathrm{z}$ automatu - istotą moralną, wraz z tym postępkiem wkroczył po raz pierwszy [na pozycję] zwierzchnika, która po upływie wielu stuleci ma go doprowadzić do samoopanowania [Selbstbeherschaft]. Droga, jaką ma odtąd pokonywać, by uzyskać zadowolenie, stała się dłuższa. $\mathrm{Na}$ początku starczyło tylko wyciągnąć rękę, aby natychmiast po [odezwaniu się] popędu uzyskać zadowolenie; teraz zaś musiał on już wprowadzić między popęd i jego zaspokojenie namysł, pilność i trud. Zniweczony został pokój między nim a zwięrzętami. Konieczność zwróciła go teraz przeciw jego uprawom, a nawet przeciw jemu samemu, a za pomocą swego rozumu musiał się sztucznie wystarać o swoje bezpieczeństwo, o przewagę sił, jakich odmówiła mu natura - musiał wynaleźć broń i dzięki solidnemu mieszkaniu zapewnić sobie przed swymi wrogami spokojny sen. Ale nawet już tu natura wynagradza mu duchowym zadowoleniem to, co odebrała mu [pozbawiając go] korzystania $\mathrm{z}$ roślin [w raju]. Samodzielnie zasadzone ziele zadziwiło go smakiem, jakiego wcześniej nie poznał; sen jaki go naszedł [beschlich] po męczącej pracy i pod własnoręcznie zbudowanym dachem okazał się słodszy niż [odpoczynek] w nudnym spokoju jego raju. Podczas walki ze zwierzętami, które go napadły, z radością odkrył siłę swych ramion oraz własną przebiegłość, a z każdym przezwyciężonym niebezpieczeństwem samemu sobie mógł dziękować za ocalenie własnego życia.

Był już zbyt szlachetny dla raju, i nie poznawał sam siebie, gdy w uległości wobec konieczności [Noth] i pod ciężarem trosk pragnął powrotu do niego. Wewnętrzny, niecierpliwy popęd $\mathrm{w}$ [stanie] próżniaczego szczęścia przezwyciężony został niebawem przez obudzony popęd do samodzielności [Selbstthätigkeit], obrzydzając mu radość, jakiej sam nie zdobył. Przemienił raj w dzikie ostępy, a następnie dzikie ostępy uczynił rajem. Na szczęście dla 
ludzkiego rodzaju nie znalazł gorszego wroga do pokonania niż znój pracy w polu, wściekłość dzikich zwierząt i wzburzenie natury! - Konieczność wywierała nań nacisk, zbudziły się namiętności i uzbroiły go wkrótce przeciwko równym mu [istotom]. Z człowiekiem musiał toczyć walkę o swoje istnienie, a ta długa, ciężka i wciąż jeszcze nie zakończona walka, jest jedynym środkiem, dzięki któremu mógł on ukształtować swój rozum i moralność.

\section{Życie domowe}

Pierwsi synowie, których zrodziła matka ludzkości, posiadali jedną istotną przewagę nad swymi rodzicami: byli wychowani przez ludzi. Wszelki postęp, jakiego musieli dokonać własnymi siłami, a więc i wiele wolniej, posłużył ich dzieciom i już w ich najmłodszym wieku został im przekazany przez zabawę, z czułością rodzicielskiej miłości. W ten sposób wraz z pierwszym synem zrodzonym przez kobietę, zapoczątkowane zostało wielkie narzędzie, [polegające na tym, że człowiek] stał się aktywny - narzędzie, dzięki któremu cały ludzki rodzaj uzyskał wykształcenie [Bildung] i wciąż będzie je zyskiwał mianowicie tradycję albo, innymi słowy, przekaz wiedzy.

Mojżeszowy dokument pozostawia nas w tym miejscu i przechodzi do okresu późniejszego o piętnaście i więcej lat, aby postawić przed nami obu braci jako już dorosłych ludzi. Jednak ten okres jest istotny dla historii ludzkości, i nawet jeśli [Mojżeszowy] dokument go pomija, to rozum powinien uzupełnić tę lukę.

Narodziny syna, wykarmienie go, opieka i wychowanie pomnażają wiedzę, doświadczenie i obowiązki pierwszych ludzi tak znacznie, że musimy starannie odnotować ten przyrost.

Pierwsza matka od zwierząt nauczyła się bez wątpienia swych najniezbędniejszych macierzyńskich obowiązków, tak jak zapewne z konieczności nauczyła się pomocy przy narodzinach. Troska o dzieci nauczyła ją nie zwracać uwagi na niezliczone drobne niewygody, które dotąd pozostały dla niej nieznane. Wzrosła liczba rzeczy, którymi nauczyła się posługiwać, czyniąc miłość matczyną przemyślną i pomysłową.

Do tej pory znali tylko jedną relację międzyludzką, tylko jeden rodzaj miłości, ponieważ każdy w drugim miał przed sobą tylko jeden przedmiot. Teraz z nowym obiektem nauczyli się nowego rodzaju miłości, nowej relacji moralnej - miłości rodzicielskiej. To nowe uczucie miłości było czystsze niż pierwsze, było zupełnie bezinteresowne, ponieważ to pierwsze opierało się na przyjemności, na wzajemnej potrzebie obcowania ze sobą. 
Wraz z tym nowym doświadczeniem wstąpili na wyższy stopień moralności - uszlachetnili się.

Ale miłość rodzicielska, w której zjednoczyli się dla [dobra] swego dziecka, spowodowała też niemałą zmianę w relacji, jaką dotąd zajmowali względem siebie. Troska, radość, czułe zaangażowanie, jakim połączył ich wspólny obiekt miłości, zawiązały między nimi nowe i piękniejsze więzi. Każde z nich przy tej sposobności w drugim odkryło nowe, moralne rysy, a każde takie odkrycie podnosiło i wysubtelniało ich związek. Mężczyzna kochał w kobiecie matkę, rodzicielkę swego ukochanego syna. Kobieta poważała i kochała w mężczyźnie ojca, żywiciela swego dziecka. Czysto zmysłowe zadowolenie sobą nawzajem przekształciło się w szacunek, a z interesownej miłości płciowej wyrosło piękne zjawisko miłości małżeńskiej.

Wkrótce wspomniane doświadczenia moralne wzbogacone zostały przez nowe. Dzieci dorosły i również między nimi zawiązała się stopniowo czuła więź. Dziecko najchętniej przebywało w towarzystwie dziecka, bo każde stworzenie kocha się tylko w stworzeniu sobie podobnym. $Z$ delikatnych, ledwie dostrzegalnych rysów wyłoniła się miłość braterska - nowe doświadczenie dla pierwszych rodziców. W tym momencie po raz pierwszy ujrzeli poza sobą obraz towarzyskości [Geselligkeit], życzliwości, i rozpoznali swoje własne uczucia, tyle tylko, że [odbite] w młodzieńczym zwierciadle.

Oboje, dopóki byli sami, żyli tylko we współczesności i przeszłości, lecz teraz, odległa przyszłość zaczęła im ukazywać ich radości. Gdy ujrzeli jak dzieci rosną u ich boku i jak każdego dnia rozwijają się w nich nowe uzdolnienia, otwierając przed nimi radosną perspektywę na przyszłość, gdy dzieci staną się kiedyś mężczyznami, [ludźmi] takimi jak oni - wówczas w ich sercu obudziło się nowe uczucie: nadzieja. Jakaż nieskończona dziedzina została przez ową nadzieję otwarta przed człowiekiem! Przedtem rozkoszowali się każdą przyjemnością tylko raz, tylko w teraźniejszości - w oczekiwaniu zaś każda przyszła radość odczuwana była w niezliczonych powtórzeniach!

Gdy dzieci rzeczywiście dorosły, jakież bogactwo pojawiło się nagle w tej pierwszej społeczności ludzkiej! Każde pojęcie, jakiego im dostarczyli, w każdej duszy inaczej się uformowało, zdumiewając ich teraz nowością. Bieg myśli stał się teraz żywy, uczucie moralne poddane zostało próbie, dzięki której rozwinęło się. Mowa stała się już bogatsza, zdolna już malować dokładniej i to bardziej subtelne uczucia. Nowe doświadczenia [zdobyte] w otaczającej naturze, nowe zastosowania już poznanych [doświadczeń]. Teraz już swoją uwagą [Aufmerksamkeit] człowiek dysponował całkowicie. Nie było już żadnego niebezpieczeństwa, że stoczy się do naśladowania zwierząt! 


\section{Różnorodność sposobów życia}

Postęp kultury ujawnił się już w pierwszym pokoleniu. Adam uprawiał pole, natomiast jeden z jego synów - jak widzimy - sięga już po nowy sposób uzyskiwania pożywienia, hodowlę bydła. Rodzaj ludzki podzielił się więc tu na dwa różne sposoby życia [Conditionen], na rolników i pasterzy.

Pierwszy człowiek wstąpił do szkoły natury, i nauczył się od niej wszelkich użytecznych rzemiosł [Künste]. Przy uważnym rozpatrzeniu nie mogła dla niego długo pozostać ukryta kolej rzeczy, wedle której powstają rośliny. Widział jak natura sama sieje i podlewa, obudził się w nim popęd do naśladowania, a niebawem również konieczność skłoniła go, by użyczyć naturze swojego ramienia i sztuką wesprzeć jej przypadkowe bogactwo.

Nie wolno jednak sądzić, że pierwsza uprawa była uprawą zboża, do czego są już niezbędne bardzo rozległe przygotowania, zgodne zaś jest $\mathrm{z}$ biegiem natury, by postępować zawsze od tego co proste do tego, co skomplikowane. Prawdopodobnie ryż był jedną z pierwszych roślin, jakie człowiek uprawiał. Natura sama go do tego zachęciła, ponieważ ryż rośnie dziko w Indiach, a najstarsze pisane historie mówią o uprawie ryżu jako o najstarszym sposobie rolnictwa. Dostrzegł następnie, że rośliny osłabione przeciągającą się suszą ponownie szybko odradzają się po deszczu. Zauważył dalej, że tam, gdzie występująca z koryta rzeka osadza muł, urodzajność [ziemi] jest większa. Posłużył się tymi dwoma odkryciami, dostarczając swym roślinom sztucznego deszczu i znosząc na swe pole muł, gdzie brakowało w pobliżu rzeki, która mogłaby mu go dostarczyć. Nauczył się nawozić i podlewać.

Trudniejszy wydaje się ten krok, którego człowiek dokonał, posługując się zwierzętami, lecz również i to zaczęło się, jak wszędzie, od tego, co zrazu naturalne i niewinne, i być może wiele ludzkich pokoleń zadowalało się mlekiem zwierząt, zanim podnieśli rękę na ich życie. Bez wątpienia mleko matki zachęciło go do próby, by posługiwać się mlekiem zwierząt. Nieprędko poznał jednak to nowe pożywienie, jak [nieprędko] się do niego trwale przekonał. Ażeby to pożywienie mieć gotowe i w zapasie, nie można było polegać na przypadku, że właśnie wtedy, gdy jest głodny, zwierzę zechce mu go dostarczyć. Wpadł na pomysł, by pewną liczbę takich zwierząt trzymać zawsze przy sobie, i założył stado, co wymagało zebrania zwierząt, które żyją gromadnie. Musiał więc przenieść je ze stanu dzikiej wolności w stan posłuszeństwa i zgodnego spokoju, tj. musiał je oswoić. Zanim jednak zdecydował się na te, które były dzikszej natury i przewyższały go przyrodzonym orężem i siłami, spróbował najpierw z tymi [zwierzętami], które on sam przewyższał 
siłą, i które z natury były mniej dzikie. Zaopiekował się najpierw owcami, aniżeli świniami, wołami aniżeli końmi.

Gdy zwierzęta pozbawione zostały wolności, człowiek został postawiony przed koniecznością samodzielnego ich nakarmienia i zaopiekowania się nimi. W ten sposób stał się pasterzem, póki zaś społeczeństwo było jeszcze niewielkie, mógł zapewnić swojemu małemu stadu pod dostatkiem pożywienia. Nie miał żadnego innego zajęcia, prócz wyszukiwania pastwisk, by, gdy [zwierzęta] już się pożywiły, zamienić pastwiska na inne. Zapłatą za tę lekką pracę był nieprzebrany dostatek, a plon jego pracy nie podlegał żadnym kaprysom, ani pór roku, ani pogody. Nieprzerwane rozkoszowanie było losem pasterskiego stanu, wolność i wesołe próżniactwo było jego cechą charakterystyczną.

Zupełnie inaczej było z rolnikiem. Był on bowiem niewolniczo przywiązany do ziemi, którą obsiewał - a wraz ze sposobem życia, jaki obrał, porzucił wszelką swobodę w obieraniu miejsca pobytu. Musiał troskliwie obchodzić się z delikatną naturą roślin, które hodował, wspomagając sztuką i pracą ich wzrost, podczas gdy drugi [brat] swoje stado pozostawiał samemu sobie. Początkowy brak narzędzi czynił pracę rolnika trudniejszą, a jednak dwoje rąk jej sprostało. Jakże uciążliwy musiał być jego sposób życia zanim ulżył mu w nim pług, zanim nie zmusił skrępowanego wołu, by dzielił z nim jego pracę!

Orka, wysiew, nawadnianie, wreszcie żniwa - jakże wiele pracy wszystko to wymagało! Ileż pracy po żniwach, by jego trud przyniósł wreszcie owoc, jakim mógłby się cieszyć! Jakże często przed dzikimi zwierzętami, które go napadały, musiał bronić swoich pól, ochraniać je i strzec ich. A być może wielokrotnie musiał walczyć z nimi, narażając się na utratę własnego życia! A przy tym jakże wciąż niepewny był owoc jego trudu, wystawiony na pastwę pogody i pór roku! Występująca z brzegów rzeka, spadający grad wystarczały, by już u celu pozbawić go wszystkiego i narazić na najsroższy niedostatek. W porównaniu ze spokojnym losem pasterza, ciężka, niestała i wątpliwa była dola rolnika, którego dusza musiała zdziczeć w ciele tak bardzo doświadczonym pracą.

Gdy przyszło mu do głowy porównać tę ciężką dolę ze szczęśliwym życiem pasterza, musiał dostrzec tę nierówność, musiał - jak podsuwała mu to jego żywa wyobraźnia - uznać go za ulubieńca niebios.

Zazdrość obudziła się w jego piersi. Nieszczęsna namiętność, która musiała zrodzić się przy [pojawieniu się] pierwszej nierówności między ludźmi. Z zawiścią spojrzał teraz na dobrobyt pasterza, który spokojnie rokoszował 
się cieniem, podczas gdy jego przypiekał żar słońca, a praca wyciskała pot z czoła. Beztroska wesołość pasterza sprawiała mu ból. Nienawidził go z powodu jego szczęścia i gardził nim z powodu jego próżniactwa. Chował względem niego utajony gniew w swym sercu, który przy najbliższej okazji musiał wybuchnąć $\mathrm{z}$ całą brutalnością. A okazja ta nie mogła długo nie nadchodzić. Przywileje każdego [z nich] nie miały w owym czasie jeszcze żadnych określonych granic, nie było też żadnych praw, które rozdzielałyby to, co moje od tego, co twoje. Każdy sądził, że ma takie samo prawo do całej ziemi, gdyż podział własności miał dopiero zostać wprowadzony w wyniku pojawiających się konfliktów. Słusznie więc pasterz wypasał swoje stada wszędzie wokół, nie mając przy tym ochoty zgubić się, zapuszczając się zbyt daleko od swej rodziny - cóż więc uczynił? Na jaki pomysł musiał w naturalny sposób wpaść? Zapędził swoje stada na pola rolnika albo przynajmniej pozwolił, ażeby same obrały tę drogę. Wszakże tam właśnie znajdowały się bogate zapasy pożywienia dla jego owiec, a nie było jeszcze żadnego prawa, które by mu tego broniło. Wszystko, po co mógł sięgnąć, było jego - w taki sposób rozumowała dziecinna jeszcze ludzkość.

W tym momencie po raz pierwszy doszło to konfliktu między ludźmi. Miejsce dzikiego zwierzęcia, z którym rolnik miał dotąd do czynienia, zajął teraz człowiek. Ten zaś okazał się być wobec niego niczym wrogie mu zwierzę, które chce spustoszyć jego ziemię. Nic dziwnego, że potraktował go w taki sposób, w jaki traktował zwierzęta, które człowiek teraz począł naśladować. Złość, którą już od lat nosił w swojej piersi, wzmogła jego wzburzenie, a śmiertelny cios maczugą w jednej chwili pomścił go za długie lata szczęścia jego sąsiada, któremu zazdrościł.

Tak oto tragicznie zakończył się pierwszy konflikt między ludźmi.

\section{Zniesiona równość stanów}

Z początkowych słów [Mojżeszowego] dokumentu wolno nam wnioskować, że poligamia w owej wczesnej epoce była czymś rzadkim, a zatem, że już wówczas istniał zwyczaj, by ograniczać się w małżeństwie i zadowalać się jedną współmałżonką. Zwyczajne małżeństwo jednak wskazywało już na pewną moralność i wyrafinowanie, jakich należało w owym wczesnym czasie oczekiwać. Przeważnie ludzie zaprowadzali porządek tylko jako skutek nieporządku, a do praw zwykle prowadziło bezprawie.

Wydaje się, że wprowadzenie zwykłego małżeństwa nie tyle oparte było na prawach, co raczej na zwyczaju. Pierwszy człowiek nie miał żyć inaczej, jak 
tylko w małżeństwie, a przykład pierwszego małżeństwa miał już dla drugiego [człowieka] poniekąd siłę prawa. Ludzki rodzaj zapoczątkowany został przez jedną parę, a zatem natura chciała mu objawić swoją wolę przez ten przykład.

Przyjmijmy, że w najbardziej pierwotnej epoce stosunek liczbowy obu płci był równy, a zatem już natura urządziła to, czego człowiek sam nie uporządkował. Każdy wziął tylko jedną żonę, bo tylko je dna mu pozostała.

Kiedy w końcu w liczbie obu płci ujawniła się pewna znacząca dysproporcja i zaistniał wybór [jakiego wcześniej nie było], wówczas porządek ten był już utrwalony rytuałem [Observanz] i nikt go nie lekceważył, by mądrość ojca naruszyć jakąś nowością.

Dokładnie w ten sposób, jak porządek małżeństwa, ukierunkował się też pewien naturalny porządek [Regiment] w społeczeństwie. Respekt wobec ojca uzasadniła sama natura, gdyż bezsilne dziecko uczyniła zależnym od ojca, od najmłodszych lat przyzwyczajając je szanować jego wolę. Uczucie to syn musiał zachować na całe swoje życie. A gdy sam stał się ojcem, jego syn nie mógł nie szanować tego, który był otoczony szacunkiem przez jego ojca, i milcząco musiał ojca swego ojca darzyć wyższym poważaniem. Szacunek względem głowy rodu [Stammherrn] musiał wzrastać w jednakowym stopniu z coraz bardziej rozrastającą się rodziną i wraz z zaawansowanym wiekiem [głowy rodu], a większe doświadczenie, owoc jego długiego życia, musiało zapewniać mu naturalną przewagę nad każdym, kto był młodszy. W każdej spornej sprawie głowa rodu była najwyższą instancją, a dzięki długiemu obcowaniu $\mathrm{z}$ takim stanem rzeczy utrwaliła się w końcu w naturalny sposób łagodna władza zwierzchnia, patriarchat, który nie zniweczył powszechnej równości, a nawet ją utrwalił.

Ale ta równość nie mogła trwać zawsze. Niektórzy byli mniej pracowici, niektórym mniej sprzyjały szczęście i ziemia, niektórzy urodzili się słabsi od innych. Istnieli zatem silni i słabi, odważni i zrezygnowani, bogaci i biedni. Słabsi i biedni musieli prosić, bogaci mogli dawać i odmawiać. Nastała [epoka] zależności ludzi od siebie.

Zgodnie z naturą rzeczy musiało dojść do tego, by ludzi w podeszłym wieku uwolnić od pracy, by młodzieniec za starca, syn za siwego ojca przejął zajęcia. Wkrótce obowiązek [nałożony przez] naturę naśladować zaczęło ludzkie celowe postępowanie. U wielu ludzi musiało zrodzić się pragnienie, by połączyć wygodny spokój starców z przyjemnością dla młodych i wkrótce postarać się o kogoś, kto przejmie za nich obowiązki synów. Jego uwaga skupiła się na biednym i słabszym, który potrzebował jego opieki albo wysuwał 
pretensje do jego dostatku. Biedny i słaby potrzebował jego wsparcia, on zaś potrzebował pilności biedaka. Jeden więc stał się sługą drugiego. Biedny i słaby służył i otrzymywał [czego mu brakowało], silny i bogaty - dawał i próżnował.

Pierwsza różnica stanów. Bogacz stał się bogatszy dzięki pilności biedaka, a powiększając swoje bogactwo, powiększał więc liczbę swoich sług. Wokół siebie widział wielu, którzy byli mniej szczęśliwi od niego, wielu rzeczywiście od niego zależało. Bogacz czuł się coraz bardziej dumny. Zaczął mylić narzędzia swego szczęścia z narzędziami swej woli. Praca wielu [ludzi] służyła dobru jednego człowieka, wnioskował więc, że owych wielu istnieje dla tego jednego - był już tylko krok od despotyzmu.

Syn bogacza zaczął uważać się za lepszego od synów sług swego ojca. Niebo miało mu sprzyjać bardziej niż im; był więc milszy niebu. Nazwał siebie synem niebios, tak jak wybrańców szczęścia nazywamy synami szczęścia. $\mathrm{W}$ porównaniu z nim, synem niebios, sługa był tylko synem ludzkim. Dlatego w Genesis istnieje rozróżnienie na synów Elohim i synów ludzkich.

Szczęście to doprowadziło bogacza do próżniactwa, próżniactwo doprowadziło go do lubieżności, a w końcu do rozpusty. Ażeby wypełnić swoje życie, musiał zwiększać liczbę swych przyjemności; nie starczała mu już zwykła miara natury, by uzyskać zadowalające go upojenie, którego szukał w uciechach swej flegmatycznej bezczynności.

Wszystko musiał mieć lepsze i wszystko w większej ilości niż sługa. Sługa zadowalał się tylko jedną małżonką. On zaś pozwalał sobie na więcej kobiet. Rozkosz coraz bardziej mu obojętniała i nudziła go. Musiał więc myśleć o tym, jak ją spotęgować za pomocą sztucznych powabów. Oto nowy krok [w dziejach ludzkości]. Nie zadowalał się już więcej tym, czym zadowalał się [w nim niegdyś] zmysłowy popęd; pragnął w rozkoszy uzyskać większą i subtelniejszą radość. Dozwolone przyjemności nie satysfakcjonowały go już; jego pożądanie natknęło się na tajemnicę. Sama kobieta nie podniecała go już więcej. Teraz wymagał już od niej także piękna.

Pośród córek swych sług wyszukiwał piękne kobiety. Jego szczęście uczyniło go dumnym, zaś duma i pewność uczyniły go hardym. Łatwo przekonał się, że wszystko, co należy do jego sług, należy też do niego. Ponieważ wszystko mu uchodziło, toteż na wszystko sobie pozwalał. Córka jego sługi, była zbyt niskiego rodu na jego małżonkę, ale posłużył się nią, by zadowolić swe pożądanie. Oto nowy znaczący krok w [od] wysubtelnienia do pogorszenia.

Skoro raz został dostarczony przykład, to upadek moralności musiał wkrótce stać się powszechny. Im mniej napotykał przymuszających go praw, 
które mogły położyć kres [jego zachowaniu], im bliżej było jeszcze stanu niewinności społeczeństwo, w którym ta niemoralność pojawia się, tym silniej musiał szerzyć się upadek moralności.

Powstało prawo silniejszego, siła usprawiedliwiła ucisk, i po raz pierwszy pojawili się tyrani.

[Mojżeszowy] dokument mówi o synach szczęścia, jako nieślubnych dzieciach, które zrodzone zostały z mieszanych związków. Jeśli można to potraktować dosłownie, w fakcie tym zawarta jest większa subtelność, czego według mnie jeszcze nie zbadano. Owe bękarty odziedziczyły dumę ojca, lecz nie jego dobroć. Być może ojciec kochał ich i faworyzował za swego życia, ale zgodnie z prawem po jego śmierci zostali wydziedziczeni i przegnani. Zostali wykluczeni z rodziny, do której weszli bezprawnie, poczuli się opuszczeni i samotni w wielkim świecie, do nikogo nie należeli, i nic nie należało do nich; wówczas jednak nie było na świecie innego sposobu życia, trzeba było być albo panem, albo sługą pana.

Nie będąc tym pierwszym, uważali się za zbyt dumnych, by być tym drugim. Byli też wychowani w zbytniej wygodzie, by nauczyć się usługiwania innym. Cóż więc mieli czynić? Pycha z powodu urodzenia i silne ramiona to wszystko, co im pozostało; tylko pamięć o niegdysiejszym dobrobycie i serce oburzone na społeczeństwo, towarzyszyły im w ich niedoli. Głód uczynił ich zbójcami, a zbójeckie szczęście do przygód w końcu zrobiło z nich bohaterów.

Wkrótce łagodny rolnik i bezbronny pasterz ze strachu i z przymusu zaczęli spełniać ich wolę. Ich szczęście i zwycięskie czyny uczyniły ich sławnymi, wygodny dostatek nowego sposobu życia wielu mogło przekonać, by przystali do ich bandy. W ten sposób, jak powiada Pismo, stali się silnymi, sławnymi ludźmi.

Ten szerzący się w pierwszym społeczeństwie nieporządek zapewne wreszcie zakończył się porządkiem, i raz usunięta równość między ludźmi, od patriarchalnych rządów doprowadziła do monarchii - jeden z owych awanturników, silniejszy od innych, ogłosił się ich panem, zbudował umocnione miasto i ustanowił pierwsze państwo - ale zjawisko to dla istoty, która kieruje losem tego świata, nadeszło zbyt wcześnie, więc straszliwe naturalne zdarzenie nagle powstrzymało wszelkie kroki, które rodzaj ludzki zamierzał uczynić dla swego wysubtelnienia. 


\section{Pierwszy król}

Azja, pozbawiona ludzkich mieszkańców wskutek powodzi, musiała rychło stać się łupem dla dzikich zwierząt, które na tak urodzajnej ziemi, jaka powstaje po wylewie, rozmnożyły się szybko i wielkiej liczbie, a ich panowanie roztoczyło się tam, gdzie człowiek był zbyt słaby, by położyć mu kres. Każdy fragment lądu, jaki ludzki rodzaj zdołał zagospodarować, miał zostać najpierw wydarty dzikim zwierzętom i przebiegłością oraz siłą zabezpieczony przed nimi na przyszłość. Nasza Europa jest obecnie wolna od swych dzikich mieszkańców, i ledwo możemy wyrobić sobie pojęcie o niedoli, jaka nękała wówczas [ludzi]. Jakże jednak straszna musiała być ta plaga, możemy wyobrazić sobie dzięki wielu miejscom Pisma, [mówiących] o zwyczajach najstarszych ludów, a zwłaszcza Greków, którzy zwycięzcom nad dzikimi zwierzętami oddawali nieśmiertelność i boską cześć.

W ten sposób królem Teb został Edyp, ponieważ pokonał przerażającego Sfinksa. W taki sposób Perseusz, Herkules, Tezeusz i wielu innych zdobyło pośmiertną sławę i boski szacunek. Kto trudził się nad tępieniem wszelkich wrogów, był wielkim dobroczyńcą ludzkości, by zaś uzyskać przy tym szczęście, musiał rzeczywiście łączyć w sobie rzadkie dary. Polowanie na te zwierzęta, zanim rozszalała się wojna między samymi ludźmi, było właściwym zajęciem bohatera. Przypuszczalnie polowanie takie urządzane było $\mathrm{w}$ formie wielkich łowów, którym przewodził najdzielniejszy, a mianowicie ten, który swoją odwagą i intelektem przejawiał naturalną wyższość nad innymi. Nadawał wówczas najważniejszym dokonaniom wojennym swoje imię, a imię to ściągało setki gotowych dołączyć do jego orszaku, by pod [jego imieniem] dokonywać walecznych czynów. Ponieważ polowania te musiały być przeprowadzane $\mathrm{w}$ pewien zaplanowany sposób - zgodnie $\mathrm{z}$ ustaleniami i pod kierunkiem przywódcy, więc on sam pozostając na boku, innym przydzielał role, czyniąc ich poddanymi jego woli. W niezauważalny sposób przyzwyczajano się stosować się [do jego woli] i podlegać jego lepszemu rozeznaniu. Dzięki czynom, śmiałości duszy i sile ramion, odznaczał się osobistą odwagą, wywołując sprzyjające mu strach i podziw, aż w końcu ślepo ulegano jego przewodnictwu. Jeśli powstawały niesnaski pośród jego towarzyszy polowań, które przy tak licznej gromadzie polujących nie mogły zbyt długo się nie pojawiać, wówczas on, którego wszyscy się obawiali i czcili, był naturalnym sędzią w sporach, a szacunek i strach przed jego osobistą odwagą wystarczał, by nadać siłę jego werdyktom. W ten sposób z przywódcy polowań stał się wodzem i sędzią. 
Gdy rozdzielano łupy, bez sprzeciwu największą ich część przydzielano jemu, przywódcy, a ponieważ sam nie był w stanie ich zużyć, dysponował dzięki temu czymś, czym mógł sobie zjednać innych, zyskując w ten sposób zwolenników i przyjaciół. Wkrótce wokół jego osoby zgromadziła się pewna liczba najdzielniejszych, których zawsze próbował pozyskać nowymi dobrodziejstwami, i niepostrzeżenie utworzył się z tego rodzaj straży przybocznej, zastęp mameluków ${ }^{2}$, którzy z dziką gorliwością chronili jego interesów, a każdego, kto chciał się im sprzeciwić, wprawiali w przerażenie z powodu swej liczebności.

Ponieważ jego polowania, dzięki oczyszczeniu granic od pustoszących je wrogów, stały się korzystne dla posiadaczy ziemskich i pasterzy, zrodziła się w nich chęć, początkowo dobrowolnego, obdarowywania go za ten pożyteczny trud owocami pola i stada, co w konsekwencji przekształciło się w zasłużoną daninę, a w końcu w dług i wymuszany haracz. Również i te nabytki rozdzielał on między najbardziej sumiennych członków swej grupy, zwiększając w ten sposób liczbę podległych mu istot. Ponieważ swe polowania coraz częściej odbywał na polach, które w wyniku tych przemarszów doznawały szkód, wielu właścicieli majątków ziemskich zaczęło żądać odkupienia tej straty dobrowolnym darem, który również później od wszystkich innych, którym mógł wyrządzić szkodę. Używając tych i innych środków powiększył swoje bogactwo, a przez nie - grono swych zwolenników, którzy w końcu urośli do rozmiarów małej armii, tak przerażającej, bo zahartowanej od wszelkiego niebezpieczeństwa i trudu $\mathrm{w}$ walce $\mathrm{z}$ lwami i tygrysami oraz zdziczałej w wyniku surowego obejścia. Jego imię roztaczało wokół strach, i nikt nie ważył się, odmówić jego prośbie. Jeśli między jednym z jego towarzyszy a kimś obcym dochodziło do sporu, wówczas myśliwy zwracał się w naturalny sposób do swego przywódcy i opiekuna, przez co ten ostatni zaczynał roztaczać swoją opiekę prawną nad istotami, które nie miały nic do czynienia z jego łowami. By stać się królem nie brakowało mu już nic, prócz uroczystego uznania, a czyż można było mu go odmówić, gdy stał na czele uzbrojonych i karnych zastępów? Był najodpowiedniejszy do tego, by panować, ponieważ był najpotężniejszy, aby przeforsować swe rozkazy. Był powszechnym dobroczyńcą wszystkich, ponieważ zawdzięczano mu spokój i bezpieczeństwo od

\footnotetext{
${ }^{2}$ Nazwy Mameluken używa Schiller w ogólnym sensie na określenie „niewolników”, a zatem zgodnie $\mathrm{z}$ arabskim znaczeniem słowa. Nie ma przy tym na myśli dawnej egipskiej gwardii przybocznej, rzeczywiście rekrutowanej z niewolników, w odniesieniu do której słowo to używane jest jako nazwa własna (przyp. tłum.).
} 
wspólnych wrogów. Był już w posiadaniu władzy, ponieważ najpotężniejsi [wojownicy] byli na jego rozkazy.

W podobny sposób zostali królami przodkowie Alaryka, Attyli, Meroweusza. Tak samo było z królami, których Homer przywołuje w Iliadzie. Wszyscy oni byli początkowo przywódcami wojowniczych hufców, zwycięzcami nad straszliwymi [istotami], dobroczyńcami swych ludów. $Z$ wojowniczych przywódców stopniowo stali się rozjemcami i sędziami, potężnymi łupami zyskali zwolenników, co uczyniło ich silnymi i budzącymi grozę. Wreszcie, przemocą sięgnęli po tron.

Przytacza się przykład Dejokes z Medii, któremu lud dobrowolnie oddał królewską godność, po czym uczynił go swoim sędzią. Jednakże postępuje się niesłusznie, podając go za przykład powstania pierwszego króla. Kiedy Medowie uczynili Dejokesa swym królem, byli już ludem, stanowili już ukształtowane polityczne społeczeństwo. W omawianym przypadku natomiast dopiero za sprawą pierwszego króla ma powstać pierwsze polityczne społeczeństwo. Medowie dźwigali ciężkie jarzmo asyryjskich monarchów, zaś król o którym mowa, był pierwszym na świecie, a lud, który mu uległ, był społeczeństwem wolnych ludzi, nieznających jeszcze żadnej władzy nad sobą. Znoszoną już niegdyś władzę bardzo dobrze można było ponownie przywrócić na pokojowej drodze, ale na tej samej pokojowej drodze nie dało się wytworzyć zupełnie nowej i nieznanej dotąd [władzy].

Wydaje się zatem zgodne ze zwykłym biegiem rzeczy, że pierwszy k ról był uzurpatorem, który osiadł na tronie nie powołany dobrowolnie i jednogłośnie przez naród (nie było bowiem wówczas jeszcze żadnego narodu), lecz przemocą i przy sprzyjającym szczęściu, przy wsparciu skłonnej do walki straży. 